\title{
Delta subfamily (version 2020.4) in the IUPHAR/BPS Guide to Pharmacology Database
}

\author{
Mohib Uddin ${ }^{1}$ \\ 1. AstraZeneca, Sweden
}

\begin{abstract}
PKCס and PKC $\theta$ are PKC isoforms that are activated by diacylglycerol and may be inhibited bycalphostin C, Gö 6983 and chelerythrine.
\end{abstract}

\section{Contents}

This is a citation summary for Delta subfamily in the Guide to Pharmacology database (GtoPdb). It exists purely as an adjunct to the database to facilitate the recognition of citations to and from the database by citation analyzers. Readers will almost certainly want to visit the relevant sections of the database which are given here under database links.

GtoPdb is an expert-driven guide to pharmacological targets and the substances that act on them. GtoPdb is a reference work which is most usefully represented as an on-line database. As in any publication this work should be appropriately cited, and the papers it cites should also be recognized. This document provides a citation for the relevant parts of the database, and also provides a reference list for the research cited by those parts.

Please note that the database version for the citations given in GtoPdb are to the most recent preceding version in which the family or its subfamilies and targets were substantially changed. The links below are to the current version. If you need to consult the cited version, rather than the most recent version, please contact the GtoPdb curators.

\section{Database links}

Delta subfamily

http://www.guidetopharmacology.org/GRAC/FamilyDisplayForward?familyld=533

Enzymes

PKCa(protein kinase C alpha)

http://www.guidetopharmacology.org/GRAC/ObjectDisplayForward?objectld=1482

$\mathrm{PKC}$ (protein kinase $\mathrm{C}$ delta)

http://www.guidetopharmacology.org/GRAC/ObjectDisplayForward?objectld=1485

PKCO(protein kinase C theta)

http://www.guidetopharmacology.org/GRAC/ObjectDisplayForward?objectld=1488

\section{References}

1. Anastassiadis T, Deacon SW, Devarajan K, Ma H and Peterson JR. (2011) Comprehensive assay of kinase catalytic activity reveals features of kinase inhibitor selectivity. Nat. Biotechnol. 29: 1039-45 [PMID:22037377]

2. Baier G, Telford D, Giampa L, Coggeshall KM, Baier-Bitterlich G, Isakov N and Altman A. (1993) Molecular cloning and characterization of PKC theta, a novel member of the protein kinase C (PKC) gene family expressed predominantly in hematopoietic cells. J. Biol. Chem. 268: 4997-5004 [PMID:8444877]

3. Belot A, Kasher PR, Trotter EW, Foray AP, Debaud AL, Rice GI, Szynkiewicz M, Zabot MT, Rouvet I and Bhaskar SS et al.. (2013) Protein kinase cठ deficiency causes mendelian systemic lupus erythematosus with B cell-defective apoptosis and hyperproliferation. Arthritis Rheum. 65: 2161-71 [PMID:23666743]

4. Birchall AM, Bishop J, Bradshaw D, Cline A, Coffey J, Elliott LH, Gibson VM, Greenham A, Hallam TJ and Harris W et al.. (1994) Ro 32-0432, a selective and orally active inhibitor of protein kinase C prevents Tcell activation. J. Pharmacol. Exp. Ther. 268: 922-9 [PMID:8114006]

5. Chand S, Mehta N, Bahia MS, Dixit A and Silakari O. (2012) Protein kinase C-theta inhibitors: a novel 
therapy for inflammatory disorders. Curr. Pharm. Des. 18: 4725-46 [PMID:22830352]

6. Davis MI, Hunt JP, Herrgard S, Ciceri P, Wodicka LM, Pallares G, Hocker M, Treiber DK and Zarrinkar PP. (2011) Comprehensive analysis of kinase inhibitor selectivity. Nat. Biotechnol. 29: 1046-51 [PMID:22037378]

7. Defauw JM, Murphy MM, Jagdmann Jr GE, Hu H, Lampe JW, Hollinshead SP, Mitchell TJ, Crane HM, Heerding JM and Mendoza JS et al.. (1996) Synthesis and protein kinase C inhibitory activities of acyclic balanol analogs that are highly selective for protein kinase C over protein kinase A. J. Med. Chem. 39: 5215-27 [PMID:8978850]

8. Faul MM, Gillig JR, Jirousek MR, Ballas LM, Schotten T, Kahl A and Mohr M. (2003) Acyclic N(azacycloalkyl)bisindolylmaleimides: isozyme selective inhibitors of PKCbeta. Bioorg. Med. Chem. Lett. 13 1857-9 [PMID:12749884]

9. Gao Y, Davies SP, Augustin M, Woodward A, Patel UA, Kovelman R and Harvey KJ. (2013) A broad activity screen in support of a chemogenomic map for kinase signalling research and drug discovery. Biochem. J. 451: 313-28 [PMID:23398362]

10. Garcia LC, Donadío LG, Mann E, Kolusheva S, Kedei N, Lewin NE, Hill CS, Kelsey JS, Yang J and Esch TE et al.. (2014) Synthesis, biological, and biophysical studies of DAG-indololactones designed as selective activators of RasGRP. Bioorg. Med. Chem. 22: 3123-40 [PMID:24794745]

11. George DM, Breinlinger EC, Friedman M, Zhang Y, Wang J, Argiriadi M, Bansal-Pakala P, Barth M, Duignan DB and Honore $\mathrm{P}$ et al.. (2015) Discovery of selective and orally bioavailable protein kinase C $\theta$ (PKC $\theta$ ) inhibitors from a fragment hit. J. Med. Chem. 58: 222-36 [PMID:25000588]

12. Gschwendt M, Dieterich S, Rennecke J, Kittstein W, Mueller HJ and Johannes FJ. (1996) Inhibition of protein kinase $\mathrm{C}$ mu by various inhibitors. Differentiation from protein kinase $\mathrm{c}$ isoenzymes. FEBS Lett. 392: 77-80 [PMID:8772178]

13. Gschwendt M, Müller HJ, Kielbassa K, Zang R, Kittstein W, Rincke G and Marks F. (1994) Rottlerin, a novel protein kinase inhibitor. Biochem. Biophys. Res. Commun. 199: 93-8 [PMID:8123051]

14. Heerding DA, Rhodes N, Leber JD, Clark TJ, Keenan RM, Lafrance LV, Li M, Safonov IG, Takata DT and Venslavsky JW et al.. (2008) Identification of 4-(2-(4-amino-1,2,5-oxadiazol-3-yl)-1-ethyl-7-\{[(3S)-3piperidinylmethyl]oxy\}-1H-imidazo[4,5-c]pyridin-4-yl)-2-methyl-3-butyn-2-ol (GSK690693), a novel inhibitor of AKT kinase. J. Med. Chem. 51: 5663-79 [PMID:18800763]

15. Jirousek MR, Gillig JR, Gonzalez CM, Heath WF, McDonald JH, Neel DA, Rito CJ, Singh U, Stramm LE and Melikian-Badalian A et al.. (1996) (S)-13-[(dimethylamino)methyl]-10,11,14,15-tetrahydro-4,9:16, 21 dimetheno-1H, 13H-dibenzo[e,k]pyrrolo[3,4-h][1,4,13]oxadiazacyclohexadecene-1,3(2H)-d ione (LY333531) and related analogues: isozyme selective inhibitors of protein kinase C beta. J. Med. Chem. 39: 2664-71 [PMID:8709095]

16. Katoh T, Takai T, Yukawa T, Tsukamoto T, Watanabe E, Mototani H, Arita T, Hayashi H, Nakagawa H and Klein MG et al.. (2016) Discovery and optimization of 1,7-disubstituted-2,2-dimethyl-2,3-dihydroquinazolin4(1H)-ones as potent and selective PKC $\theta$ inhibitors. Bioorg. Med. Chem. 24: 2466-75 [PMID:27117263]

17. Kedei N, Lundberg DJ, Toth A, Welburn P, Garfield SH and Blumberg PM. (2004) Characterization of the interaction of ingenol 3-angelate with protein kinase C. Cancer Res. 64: 3243-55 [PMID:15126366]

18. Kuehn HS, Niemela JE, Rangel-Santos A, Zhang M, Pittaluga S, Stoddard JL, Hussey AA, Evbuomwan MO, Priel DA and Kuhns DB et al.. (2013) Loss-of-function of the protein kinase C $\delta$ (PKC $\delta$ ) causes a Bcell lymphoproliferative syndrome in humans. Blood 121: 3117-25 [PMID:23430113]

19. Kwon MJ, Wang R, Ma J and Sun Z. (2010) PKC- $\theta$ is a drug target for prevention of T cell-mediated autoimmunity and allograft rejection. Endocr Metab Immune Disord Drug Targets 10: 367-72 [PMID:20923402]

20. Luzzio MJ, Papillon J and Visser MS. (2016) Protein kinase C inhibitors and methods of their use Patent number: WO2016020864A1.

21. Martiny-Baron G, Kazanietz MG, Mischak H, Blumberg PM, Kochs G, Hug H, Marmé D and Schächtele C. (1993) Selective inhibition of protein kinase C isozymes by the indolocarbazole Gö 6976. J. Biol. Chem. 268: 9194-7 [PMID:8486620]

22. Monks CR, Kupfer H, Tamir I, Barlow A and Kupfer A. (1997) Selective modulation of protein kinase Ctheta during T-cell activation. Nature 385: 83-6 [PMID:8985252]

23. Seynaeve CM, Kazanietz MG, Blumberg PM, Sausville EA and Worland PJ. (1994) Differential inhibition of protein kinase C isozymes by UCN-01, a staurosporine analogue. Mol. Pharmacol. 45: 1207-14 [PMID:8022414]

24. Tanaka M, Sagawa S, Hoshi J, Shimoma F, Matsuda I, Sakoda K, Sasase T, Shindo M and Inaba T. (2004) Synthesis of anilino-monoindolylmaleimides as potent and selective PKCbeta inhibitors. Bioorg. Med. Chem. Lett. 14: 5171-4 [PMID:15380221]

25. Toullec D, Pianetti $P$, Coste H, Bellevergue P, Grand-Perret T, Ajakane M, Baudet V, Boissin P, Boursier $\mathrm{E}$ and Loriolle $\mathrm{F}$ et al.. (1991) The bisindolylmaleimide GF 109203X is a potent and selective inhibitor of protein kinase C. J. Biol. Chem. 266: 15771-81 [PMID:1874734]

26. Uddin M, Seumois G, Lau LC, Davies DE and Djukanovic R. (2006) Activation of neutrophils by the repairing epithelium is regulated via PI3-kinase/Akt/PKCdelta-mediated signals Thorax (BTS suppl 2)61: S21

27. Wagner J, von Matt P, Sedrani R, Albert R, Cooke N, Ehrhardt C, Geiser M, Rummel G, Stark W and Strauss A et al.. (2009) Discovery of 3-(1H-indol-3-yl)-4-[2-(4-methylpiperazin-1-yl)quinazolin-4-yl]pyrrole2,5-dione (AEB071), a potent and selective inhibitor of protein kinase C isotypes. J. Med. Chem. 52: 61936 [PMID:19827831] 
28. Wilkinson SE, Parker PJ and Nixon JS. (1993) Isoenzyme specificity of bisindolylmaleimides, selective inhibitors of protein kinase C. Biochem. J. 294 ( Pt 2): 335-7 [PMID:8373348]

29. Wodicka LM, Ciceri P, Davis MI, Hunt JP, Floyd M, Salerno S, Hua XH, Ford JM, Armstrong RC and Zarrinkar PP et al.. (2010) Activation state-dependent binding of small molecule kinase inhibitors: structural insights from biochemistry. Chem. Biol. 17: 1241-9 [PMID:21095574]

30. Xu ZB, Chaudhary D, Olland S, Wolfrom S, Czerwinski R, Malakian K, Lin L, Stahl ML, Joseph-McCarthy $\mathrm{D}$ and Benander C et al.. (2004) Catalytic domain crystal structure of protein kinase C-theta (PKCtheta).J. Biol. Chem. 279: 50401-9 [PMID:15364937]

31. Zanin-Zhorov A, Dustin ML and Blazar BR. (2011) PKC- $\theta$ function at the immunological synapse: prospects for therapeutic targeting. Trends Immunol. 32: 358-63 [PMID:21733754] 